\title{
The prevalence of Borrelia miyamotoi infection, and co-infections with other Borrelia spp. in Ixodes scapularis ticks collected in Canada
}

\author{
Antonia Dibernardo ${ }^{1 *}$, Tyler Cote ${ }^{1 \dagger}$, Nicholas H Ogden ${ }^{2+}$ and L Robbin Lindsay ${ }^{1 \dagger}$
}

\begin{abstract}
Background: Blacklegged ticks, Ixodes scapularis are vectors of the tick-borne pathogens Borrelia burgdorferi, Anaplasma phagocytophilum and Babesia microti. Recently, the I. scapularis-borne bacterium Borrelia miyamotoi has been linked to human illness in North America. The range of this tick is expanding in Canada which may increase the potential for human exposure to these agents.

Methods: In this study, 4938 I. scapularis ticks collected in 2012 were tested following a newly developed PCR-based testing protocol to determine the prevalence of infection with B. miyamotoi and other pathogens in I. scapularis in Canada.

Results: Borrelia miyamotoi was detected in blacklegged ticks from all provinces except Newfoundland, although the infection prevalence was low $(<1 \%)$. There was significant variation among provinces in the prevalence of infection of ticks with B. burgdorferi and A. phagocytophilum, but not with B. miyamotoi.

Conclusions: Given the widespread distribution of B. miyamotoi, infection due to this agent should be considered in patients who have been exposed to blacklegged ticks in Canada.
\end{abstract}

Keywords: Borrelia miyamotoi, Lyme disease, Real-time PCR, Co-infection

\section{Background}

Borrelia miyamotoi was first described in Ixodes persulcatus ticks and in the blood of rodents collected in Japan in the early 1990s [1]. Subsequently, B. miyamotoi was detected, for the first time in North America, associated with blacklegged ticks, Ixodes scapularis in several states in the Northeastern United States [2]. Infection rates in field-collected nymphal I. scapularis were 1.9-2.5\% [2] and unlike the agent of Lyme disease, Borrelia burgdorferi, B. miyamotoi is transmitted vertically from infected female I. scapularis to a variable proportion of larval progeny $[2,3]$. Initially the public health significance of B. miyamotoi was poorly understood; however, recent studies in Russia demonstrate that Old World strains of B. miyamotoi, transmitted by I. persulcatus cause an

\footnotetext{
* Correspondence: antonia.dibernardo@phac-aspc.gc.ca

${ }^{\dagger}$ Equal contributors

'Public Health Agency of Canada, Zoonotic Diseases and Special Pathogens, National Microbiology Laboratory, 1015 Arlington Street, Winnipeg,

Manitoba, Canada

Full list of author information is available at the end of the article
}

influenza-like illness with relapsing fever [4]. In North America, meningoencephalitis was recently described in an elderly immunocompromised patient [5] and results of a serosurvey of patients from southern New England and New York demonstrate that B. miyamotoi infection can cause a viral-like illness [6]. These studies support the contention that B. miyamotoi is yet another of the guild of pathogens, which includes the agents of Lyme disease, anaplasmosis, babesiosis, Powassan virus and the Ehrlichia muris-like agent, associated with blacklegged ticks in North America [7]. The discovery of DNA of $B$. miyamotoi in ticks during a study of B. burgdorferi diversity signaled the possible occurrence of $B$. miyamoto $i$ in Canada [8].

Passive surveillance for blacklegged ticks, which involves the submission of ticks collected by the general public and participating medical and veterinary clinics, has been conducted across Canada (excluding British Columbia) since the 1990s $[9,10]$. Ticks identified as I. scapularis have been routinely tested for infection with 
B. burgdorferi and Anaplasma phagocytophilum using first a multiplex real-time PCR assay [11], followed by an ospA real-time PCR to confirm B. burgdorferi infection [9]. Most I. scapularis are submitted from locations where reproducing populations of I. scapularis occur (southern Manitoba, southern and eastern Ontario, southern Quebec, and locations in New Brunswick and Nova Scotia). Some I. scapularis are also submitted from locations where populations are not known to occur (e.g. Alberta, Saskatchewan, Prince Edward Island and Newfoundland) and it is thought that these ticks are 'adventitious' ticks dispersed from tick populations in Canada and the USA by migratory birds [9]. Each year a small number of I. scapularis submitted in passive surveillance test positive for Borrelia species infection in the 23S rRNA real-time PCR screening assay but are negative for $B$. burgdorferi infection in the confirmatory ospA real-time PCR assay. Subsequent testing by nested PCR (nPCR) and sequencing indicate that some of these extracts are positive for infection with B. miyamotoi. This supports earlier Multilocus Sequence Typing (MLST) analysis in which a small number of B. burgdorferi-infected ticks were found to be co-infected with B. miyamotoi [8].

We have developed and evaluated molecular assays to identify B. miyamotoi and a PCR-based testing protocol or diagnostic approach for testing I. scapularis ticks collected in surveillance for tick-borne agents. Data on the western blacklegged tick I. pacificus, and B. miyamotoi prevalence were not addressed by this study. Here we undertake a systematic analysis of ticks recently collected in surveillance in Canada to i) better understand the possible geographic range of $B$. miyamoto $i$ in Canada; ii) estimate the prevalence of $B$. miyamoto infection in I. scapularis ticks in Canada; and iii) investigate the frequency of co-infections with $B$. miyamotoi, $B$. burgdorferi and A. phagocytophilum in I. scapularis in Canada.

\section{Methods}

Development of B. miyamotoi-specific IGS real-time PCR DNA from 25 ticks collected in surveillance prior to 2012 that tested positive with the screening 23S rRNA real-time PCR, but negative with the confirmatory ospA real-time PCR was tested with a $\mathrm{nPCR}$ specific to the genus Borrelia [12] which amplifies 587 bp of the $16 \mathrm{~S}$ 23S IGS region. For this PCR, $5 \mu \mathrm{l}$ DNA template was added to $95 \mu$ l master mix containing $0.2 \mathrm{mM}$ each dNTP, $0.5 \mu \mathrm{M}$ forward and reverse primers, 5 Units of AmpliTaq Gold ${ }^{\circledR}$ polymerase and $1.5 \mathrm{mM} \mathrm{MgCl}_{2}$ (Life Technologies, Carlsbad, CA). The thermocycler conditions used were as follows: denaturation at $94^{\circ} \mathrm{C}$ for $4 \mathrm{mi}-$ nutes, 35 cycles of amplification at $94^{\circ} \mathrm{C}$ for 1 minute, $50^{\circ} \mathrm{C}$ for 1 minute and $72^{\circ} \mathrm{C}$ for 1 minute, followed by a 10 minute extension phase at $72^{\circ} \mathrm{C}$ for both stages of the nested PCR reaction. Amplification products were analyzed by ethidium bromide-stained $2 \%$ agarose gels. All nPCR products were purified using Montage ${ }^{\circ} \mathrm{PCR}$ filter units (Millipore) and sequenced on an ABI 3130xl Genetic Analyzer using BigDye ${ }^{\mathrm{Tm}}$ Terminator version 3.1 cycle sequencing kits. Sequence data was analyzed using DNASTAR Lasergene 9 Software and multiple alignments were performed using Clustal W. Sequences were compared to those in GenBank and BLAST results indicated that 8 of the 25 tick extracts were positive for B. miyamotoi. Subsequently, B. miyamotoi-specific and B. burgdorferi-specific primers and FAM-labeled probes annealing to the 16S-23S IGS were designed from these sequences for real-time IGS PCR (Table 1).

\section{Validation of real-time PCR}

Validation of the species-specific IGS real-time PCR assays was performed using DNA from the eight $23 \mathrm{~S}$ PCR-positive and ospA PCR-negative ticks mentioned previously, DNA from 72 ticks (collected from 2008 to 2012) that were positive on both the $23 \mathrm{~S}$ and the $\operatorname{spA}$ real-time PCR confirming $B$. burgdorferi infection, and DNA from 9 ticks that were 23S PCR-positive and ospA PCR-negative and had been confirmed as being infected with $B$. bissettii by flagellin nPCR. DNA from cultures of B. garinii strain ATCC $51991^{\mathrm{TM}}$ and B. afzelii strain ATCC $^{\oplus} 51567^{\mathrm{m}}$, and $B$. hermsii DNA from a clinical sample was used to evaluate the specificity of the assays. Once validated, the species-specific real-time PCR assays were applied to DNA from an additional 39 23S PCRpositive and ospA PCR-negative ticks collected during 2008-2012.

Reaction mixtures were prepared in $2 \mathrm{x}^{\mathrm{TaqMan}}{ }^{\bullet}$ Universal Mastermix (Applied Biosystems, Life Technologies) to contain 300 to $600 \mathrm{nM}$ of each primer and $200 \mathrm{nM}$ probe. Amplification was carried out on either an ABI 7500 Real-time PCR System, ABI 7900HT or ABI ViiA7 using 96 well optical plates. Thermocycling conditions consisted of: activation of AmpErase at $50^{\circ} \mathrm{C}$ for 2 minutes, $10 \mathrm{mi}$ nutes at $95^{\circ} \mathrm{C}$ for denaturation of AmpErase and activation of AmpliTaq Gold ${ }^{\circledR}$ Polymerase, followed by 40 cycles of amplification with denaturation at $95^{\circ} \mathrm{C}$ for 15 seconds and annealing at $58^{\circ} \mathrm{C}$ for 1 minute. Following amplification and real-time data acquisition, analysis was performed using the Sequence Detection System software. A second real-time PCR assay targeting B. miyamotoi glpQ [13] was performed as a confirmatory assay, using an annealing temperature of $50^{\circ} \mathrm{C}$.

DNA from B. miyamotoi-positive, B. bissettii-positive and most $B$. burgdorferi-positive ticks was tested using the nested 16S-23S IGS PCR to generate products for sequencing. This sequence data was considered the gold standard and provided validation data for the B. miyamotoi real-time PCR assays. 
Table 1 Primer and probe sequences for the detection of A. phagocytophilum and Borrelia species

\begin{tabular}{|c|c|c|c|}
\hline & & Primer/Probe & 5'-3' nucleotide sequence \\
\hline \multicolumn{4}{|c|}{ Duplex screening assay } \\
\hline & & $\mathrm{Bb} 23 \mathrm{Sf}$ & CGAGTCTTAAAAGGGCGATTTAGT \\
\hline \multirow[t]{3}{*}{ B. burgdorferi } & $23 S$ rRNA & $\mathrm{Bb} 23 \mathrm{Sr}$ & GCTTCAGCCTGGCCATAAATAG \\
\hline & & Bb23S-P & FAM-AGATGTGGTAGACCCGAAGCCGAGTG-TAMRA \\
\hline & & ApMSP2f & ATGGAAGGTAGTGTTGGTTATGGTATT \\
\hline \multirow[t]{2}{*}{ A. phagocytophilum } & msp2 & ApMSP2r & TTGGTCTTGAAGCGCTCGTA \\
\hline & & ApMSP2-P & VIC-TGGTGCCAGGGTTGAGCTTGAGATTG-TAMRA \\
\hline \multicolumn{4}{|c|}{ B. burgdorferi confirmatory assay(s)* } \\
\hline & & ospAF & CTGGGGAAGTITCAGTTGAAC \\
\hline \multirow[t]{3}{*}{ B. burgdorferi } & ospA & ospAR & TTGGTGCCATTTGAGTCGTA \\
\hline & & ospA-P & FAM-CTGCAGCTTGGAATTCAGGCACTT-BBQ \\
\hline & & BblGSf & AAGAAGGACAAGTATTGTAGCGAG \\
\hline \multirow[t]{2}{*}{ B. burgdorferi } & $\mathrm{IGS}^{*}$ & $\mathrm{Bb} \mid \mathrm{GS} r$ & GCAATCTTTGCCTTCCTCC \\
\hline & & BbIGS-P & FAM-TGCCAGTATTTAGTGGTAGGGATTCGG-BBQ \\
\hline \multicolumn{4}{|l|}{ B. miyamotoi assays } \\
\hline & & BmiyalGSf & CGTCTTGTTGCTITIAAAGTGT \\
\hline \multirow[t]{3}{*}{ B. miyamotoi } & IGS & BmiyalGSr & CATGATCAGGTCCTTGATAATATG \\
\hline & & BmiyalGS-P & FAM-TGGATTCCAAATTTGATTACATGCAA-BBQ \\
\hline & & MGlpQF & GATAATATTCCTGTTATAATGC \\
\hline \multirow[t]{2}{*}{ B. miyamotoi } & glpq & MGlpQR & CACTGAGATTTAGTGATTTAAGTTC \\
\hline & & MYS-P & FAM-CCCAGAAATTGACAACCACAAATGT-BHQ2 \\
\hline \multicolumn{4}{|c|}{ Borrelia spp. Nested PCR } \\
\hline \multirow[t]{4}{*}{$16 S-23 S$ IGS } & 1st stage & rrs & GTATGTITAGTGAGGGGGGTG \\
\hline & & $\mathrm{rrl}$ & GGATCATAGCTCAGGTGGTTAG \\
\hline & 2nd stage & $\mathrm{Fn}$ & AGGGGGGTGAAGTCGTAACAAG \\
\hline & & $\mathrm{Rn}$ & GTCTGATAAACCTGAGGTCGGA \\
\hline \multirow[t]{4}{*}{ Flagellin } & 1st stage & $\mathrm{FO} 1$ & AAGTAGAAAAAGTCTTAGTAAGAATGAAGGA \\
\hline & & $\mathrm{FO} 2$ & AATTGCATACTCAGTACTATTCTTTATAGAT \\
\hline & 2nd stage & Fl1 & CACATATTCAGATGCAGACAGAGGTTCTA \\
\hline & & $\mathrm{Fl} 2$ & GAAGGTGCTGTAGCAGGTGCTGGCTGT \\
\hline
\end{tabular}

${ }^{*} B$. burgdorferi IGS real-time PCR is performed solely for validation of the specificity of $B$. miyamotoi real-time PCR assays and is not routinely used in the testing protocol.

\section{Analysis of infections and co-infections in I. scapularis ticks collected in passive surveillance}

A total of 4938 I. scapularis ticks collected in passive surveillance in 2012 (excluding the 68 used in validation) were tested using the developed testing protocol (Figure 1). The screening $23 \mathrm{~S}$ and confirmatory ospA real-time PCR were used to assess $B$. burgdorferi infection as described above. The screening 23S PCR is a multiplex assay that also detects the presence of $A$. phagocytophilum DNA using primers specific for the $m s p 2$ gene (ApMSP2f and ApMSP2r) [14]. Confirmation of infection with A. phagocytophilum is achieved by an in-house real-time PCR assay targeting 16S rRNA. The Borrelia miyamotoi-specific IGS real-time PCR was used to detect $B$. miyamotoi infections that were subsequently confirmed by $B$. miyamotoi $g l p Q$ real-time PCR. All real-time PCR assays were conducted using the conditions described above for B. miyamotoi IGS. Tick extracts that were positive for Borrelia spp. infection in the screening $23 S$ real-time PCR, but negative for $B$. burgdorferi in the ospA real-time PCR, and negative in the B. miyamotoi IGS assay, were tested by $16 \mathrm{~S}-23 \mathrm{~S}$ IGS nPCR with the aim of sequencing products to identify other infecting Borrelia species.

Associations of infections and co-infections in ticks with province of origin, level of engorgement of the tick, host of origin, and tick instar were investigated by logistic regression in STATA version 11.0 for Windows (STATACorp, College Station, TX, USA). The most 


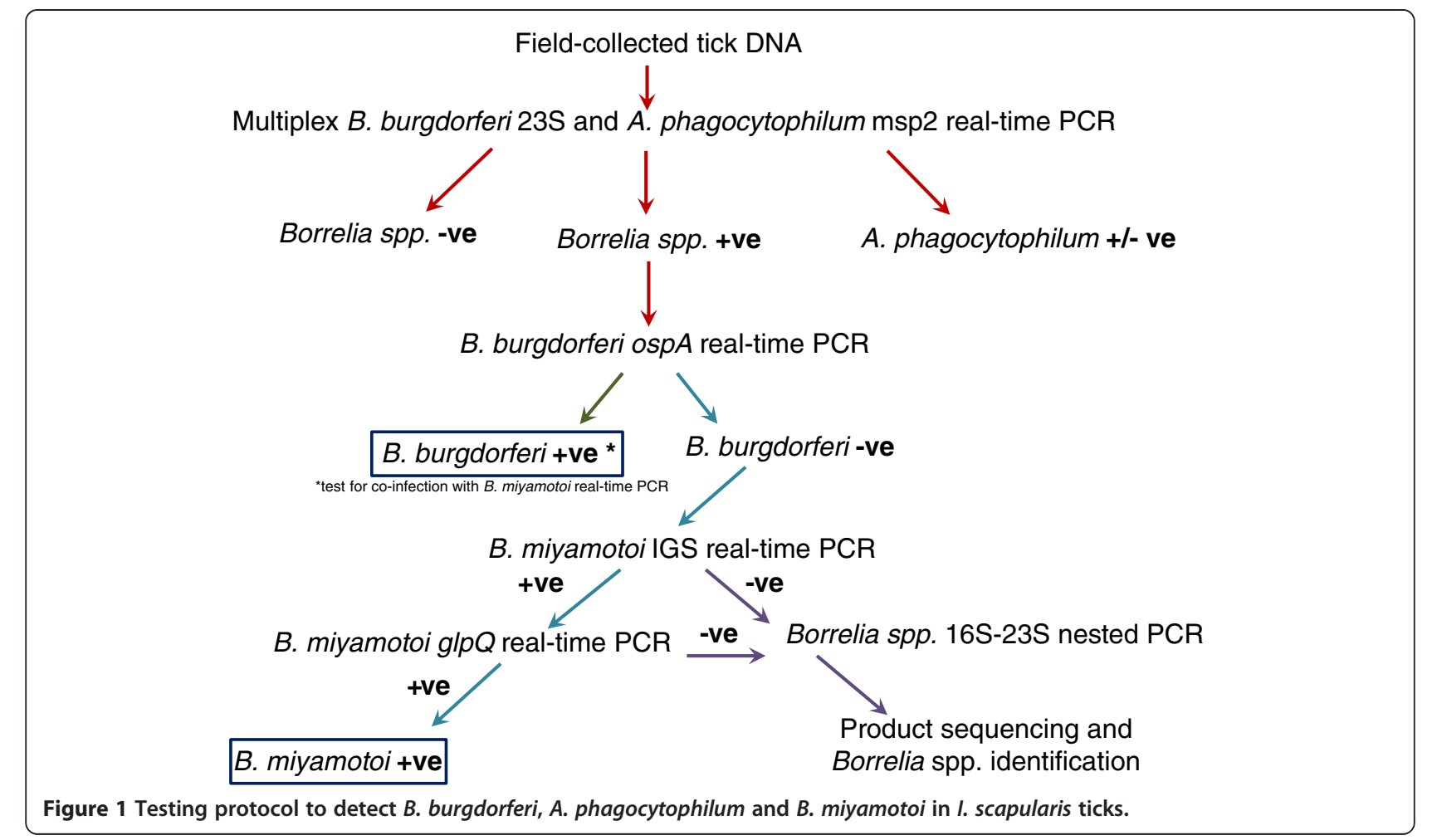

parsimonious multivariable model was created by backwards and forwards elimination and substitution of variables. Logistic regression models were used to investigate whether or not there were significant associations between infections of ticks with different pathogens. The level of significance throughout was $\mathrm{P}<0.05$.

\section{Results}

Development and validation of B. miyamotoi-specific IGS real-time PCR

Primers were developed using a sequence with 100\% similarity to a sequence from B. miyamotoi (GenBank: AY531879) obtained in the 16S-23S IGS nPCR. All 8 (100\%) of the B. miyamotoi-positive ticks, that were so determined by $16 \mathrm{~S}-23 \mathrm{~S}$ IGS nPCR and sequencing, were positive by $B$. miyamotoi IGS and $g l p Q$ real-time PCR. These extracts were also negative in the $B$. burgdorferi IGS real-time PCR assay. All 72 (100\%) of the B. burgdorferi extracts were positive in the B. burgdorferi IGS real-time PCR. Two of $72(2.8 \%)$ of these extracts were also reactive with $B$. miyamotoi IGS and $g l p Q$ real-time PCR indicating co-infection. The nine extracts known to be positive for $B$. bissettii, DNA from cultures of $B$. afzelii and B. garinii did not react in either the B. burgdorferi or B. miyamotoi IGS or $g l p Q$ real-time PCR assays. DNA of $B$. hermsii did not react in either the $B$. miyamoto $i$ IGS or $g l p Q$ real-time PCR but produced a late amplification product $(\mathrm{Ct}>39)$ in the B. burgdorferi IGS real-time PCR. Of the $3923 \mathrm{~S}$ rRNA-positive ospA-negative ticks obtained in 2008-2012, 31 (79.5\%) were positive for B. miyamotoi, while one extract was also coinfected with $B$. bissettii. In total, $7 / 39$ (17.9\%) of the extracts were negative by IGS real-time PCR and were subsequently identified as $B$. bissettii by sequencing of products of the 16S-23S IGS nPCR. One of the 39 extracts was positive for $B$. burgdorferi by IGS real-time PCR and subsequently confirmed with 16S-23S IGS sequencing. The reactivity profiles of $B$. burgdorferi, $B$. miymotoi and $B$. bissettii in the various PCR assays (Table 2) serve as the basis for our testing protocol to detect the suite of Borrelia species found in blacklegged ticks collected in Canada.

\section{Analysis of infections and co-infections in I. scapularis ticks collected in passive surveillance}

Of the 4938 ticks tested (Table 3), 41 (0.8\%) were infected with $A$. phagocytophilum (0/4 larvae, 0/139 nymphs, 37/ 4778 adults), 696 (14.1\%) were infected with B. burgdorferi (0/4 larvae, 16/139 nymphs, 676/4778 adults) and 23 $(0.5 \%)$ were infected with $B$. miyamotoi (0/4 larvae, $1 / 139$ nymphs, 22/4778 adults) (Tables 4 and 5). No other Borrelia spp. were detected in the ticks.

Borrelia miyamotoi was found in blacklegged ticks from all provinces except Newfoundland, and there were no significant variations amongst provinces in the prevalence of B. miyamotoi infection of ticks. All 
Table 2 PCR reactivity profiles for Borrelia species detected in 1 . scapularis ticks in Canada

\begin{tabular}{lccc}
\hline & \multicolumn{3}{c}{ Borrelia species } \\
\cline { 2 - 4 } PCR reaction & B. burgdorferi & B. miyamotoi & B. bissettii \\
\hline Real-time PCR & & & \\
23 rRNA & + & + & + \\
OSPA & + & - & - \\
B.burgdorferi IGS & + & - & - \\
B. miyamotoi IGS & - & + & - \\
B. miyamotoi glpQ & - & + & - \\
Conventional nested PCR & & & \\
Flagellin & + & - & $+/-$ \\
OSPA & + & - & $+/-$ \\
$16 S-23 S$ IGS & + & + & + \\
\hline
\end{tabular}

other explanatory variables were not significantly associated with $B$. miyamotoi infection.

There were significant variations amongst provinces in the likelihood that a tick was positive for B. burgdorferi. The provinces could be simplified into three groups within which the prevalence of infection was similar: i) Alberta and Manitoba, ii) New Brunswick and Prince Edward Island, and iii) ticks from all other provinces (Ontario, Quebec, Nova Scotia and Newfoundland) $\left(X^{2}=4.8, \mathrm{df}=5, \mathrm{P}>0.1\right)$. Ticks from New Brunswick and Prince Edward Island were significantly less likely to be infected with B. burgdorferi than ticks from Ontario, Quebec, Nova Scotia and Newfoundland combined (OR $=0.55,95 \%$ $\mathrm{CI}=0.39-0.78, \mathrm{P}<0.01$ ), and less likely to be infected than ticks in Alberta and Manitoba (by Wald test of final model parameters: $X^{2}=14.7, \mathrm{df}=1, \mathrm{P}<0.001$ ). Ticks from Alberta and Manitoba were less likely to be infected with
B. burgdorferi than ticks from Ontario, Quebec, Nova Scotia and Newfoundland combined (OR $=0.64,95 \%$ $\mathrm{CI}=0.41-0.98, \mathrm{P}<0.05)$. Ticks were significantly less likely to be infected if they fed on humans $(\mathrm{OR}=0.59,95 \%$ $\mathrm{CI}=0.46-0.75, \mathrm{P}<0.001$ ), and were less likely to be infected if they were slightly, partially or fully engorged than if they were unfed (ORs $=0.44,0.30,0.21 ; 95 \%$ CIs $=0.33$ 0.60, 0.24-0.39, 0.10-0.44; $\mathrm{P}<0.001$ for all).

No immature ticks were infected with A. phagocytophilum but there was significant variation amongst province of origin in the proportion of adult ticks infected with A. phagocytophilum. Adult ticks collected in Alberta and Manitoba were significantly more likely to be infected than ticks from other locations $(\mathrm{OR}=4.5,95 \% \mathrm{CI}=2.0$ 10.4, $\mathrm{P}<0.001)$. Ticks from Quebec were significantly more likely to be infected than ticks from Ontario, New Brunswick, Nova Scotia and Newfoundland combined $(\mathrm{OR}=3.7,95 \% \mathrm{CI}=1.7-7.7, \mathrm{P}<0.001)$. There were no significant variations in prevalence of $A$. phagocytophilum infection associated with state of engorgement or host of origin.

Co-infections were detected in 19 ticks (15 being adult females, one being an adult male and 3 having the instar unrecorded), of which 11 ( $0.23 \%$ of adult ticks) were coinfected with $A$. phagocytophilum and B. burgdorferi, and $8(0.17 \%$ of adult ticks $)$ were co-infected with B. burgdorferi and B. miyamotoi (Tables 4 and 5). Consequently statistical analysis was limited to adult ticks. Adult ticks were significantly more likely to be infected with $B$. miyamoto $i$ if they were infected with B. burgdorferi $(\mathrm{OR}=3.5,95 \% \mathrm{CI}=1.5-8.4, \mathrm{P}<0.01)$. This relationship remained significant when other variables (province of origin, level of engorgement of the tick, host of origin, and tick instar) were included in the model. There was no significant association between

Table 3 Collection data by province for I. scapularis ticks submitted through passive surveillance in 2012

\begin{tabular}{|c|c|c|c|c|c|c|c|c|c|c|}
\hline \multirow[t]{2}{*}{ Province } & \multirow[t]{2}{*}{ Total no. ticks } & \multicolumn{3}{|c|}{ Instar* } & \multicolumn{2}{|c|}{ State of engorgement ${ }^{\dagger}$} & \multicolumn{4}{|c|}{ Host } \\
\hline & & Larvae & Nymphs & $\overline{\text { Adults }}$ & Unfed & Fed & Dog & Cat & Human & Other \\
\hline$A B$ & 87 & & & 87 & & 87 & 78 & 9 & & \\
\hline$M B$ & 170 & & 13 & 152 & 51 & 115 & 98 & 16 & 53 & 1 \\
\hline ON & 2591 & 4 & 97 & 2482 & 1397 & 1183 & 445 & 28 & 2102 & 7 \\
\hline NB & 366 & & 14 & 350 & 76 & 285 & 187 & 21 & 123 & 7 \\
\hline $\mathrm{NL}$ & 33 & & 1 & 32 & 3 & 30 & 20 & 10 & 3 & \\
\hline NS & 34 & & & 34 & 9 & 24 & 21 & & 13 & \\
\hline PEl & 178 & & 1 & 176 & 8 & 168 & 139 & 28 & 11 & \\
\hline QC & 1479 & & 13 & 1465 & 297 & 1179 & 919 & 129 & 427 & 3 \\
\hline Total & 4938 & 4 & 139 & 4778 & 1841 & 3071 & 1907 & 241 & 2732 & 18 \\
\hline
\end{tabular}

*Of the adult ticks 61 were males the rest females and for 17 ticks the instar was not recorded.

${ }^{\dagger}$ For 26 ticks the state of engorgement was not recorded.

$\mathrm{AB}=$ Alberta, $\mathrm{MB}=$ Manitoba, $\mathrm{ON}=$ Ontario, NB = New Brunswick, NL = Newfoundland \& Labrador, NS $=$ Nova Scotia, PEI $=$ Prince Edward Island, $\mathrm{QC}=\mathrm{Quebec}$,

$\mathrm{Ap}=\mathrm{A}$. phagocytophilum, $\mathrm{Bb}=\mathrm{B}$. burgdorferi and $\mathrm{Bm}=B$. miyamotoi. 
Table 4 Prevalence of infection of ticks* with A. phagocytophilum, B. burgdorferi and B. miyamotoi by province

\begin{tabular}{|c|c|c|c|c|c|c|c|}
\hline \multicolumn{2}{|c|}{ Province total no. ticks } & \multicolumn{2}{|c|}{ Number (\%) infected } & \multicolumn{4}{|c|}{ Number (\%) co-infected } \\
\hline & & Ap & $\mathrm{Bb}$ & $\mathrm{Bm}$ & $A p-B b$ & Ap-Bm & $\mathrm{Bb}-\mathrm{Bm}$ \\
\hline$A B$ & 87 & $5(5.7)$ & $12(13.8)$ & $1(1.1)$ & $1(1.1)$ & & \\
\hline $\mathrm{MB}$ & 170 & $5(2.9)$ & $15(8.8)$ & $2(1.2)$ & $3(1.8)$ & & \\
\hline ON & 2591 & $7(0.3)$ & $411(15.9)$ & $7(0.3)$ & $2(0.08)$ & & $2(0.08)$ \\
\hline NB & 366 & $3(0.8)$ & $25(6.8)$ & $3(0.8)$ & $1(0.3)$ & & \\
\hline $\mathrm{NL}$ & 33 & $1(3.0)$ & $9(27.3)$ & & $1(3.0)$ & & \\
\hline NS & 34 & & $4(11.8)$ & $1(2.9)$ & & & $1(2.9)$ \\
\hline PEl & 178 & $1(0.6)$ & $17(9.6)$ & $1(0.6)$ & & & \\
\hline QC & 1479 & $19(1.3)$ & $203(13.7)$ & $8(0.5)$ & $3(0.2)$ & & $5(0.3)$ \\
\hline Total & 4938 & $41(0.8)$ & $696(14.1)$ & $23(0.5)$ & $11(0.2)$ & 0 & $8(0.2)$ \\
\hline
\end{tabular}

*. scapularis ticks collected by passive surveillance in 2012.

A. phagocytophilum and B. burgdorferi infection in adult ticks.

\section{Discussion}

The objective of this study was to develop and implement a systematic approach using real-time PCR assay to detect B. miyamotoi, B. burgdorferi and A. phagocytophilum infections and co-infections in ticks collected in surveillance. In doing so, we were able to assess the prevalence of infection of ticks collected in Canada, with the newly-recognized pathogen B. miyamotoi. Results of our study identified $B$. miyamotoi-infected ticks at low $(<1 \%)$ prevalence in most provinces. Few ticks were coinfected, however a third of $B$. miyamotoi-infected ticks and a quarter of $A$. phagocytophilum-infected ticks were also infected with $B$. burgdorferi and co-infections of $B$. miyamotoi and B. burgdorferi occurred more frequently than would be expected by chance.

It is increasingly recognized that I. scapularis ticks transmit a range of bacteria including the Lyme diseasecausing B. burgdorferi, B. miyamotoi, the E. muris-like agent [15], and $A$. phagocytophilum [16] as well as bacteria such as B. carolinensis [17] and B. bissettii [18]

Table 5 Prevalence of infection of I. scapularis ticks ${ }^{\dagger}$ by instar*

\begin{tabular}{lccc}
\hline & \multicolumn{3}{c}{ Tick Instar } \\
\cline { 2 - 4 } Pathogen & Larvae & Nymphs & Adults \\
\hline B. miyamotoi & $0 / 4(0)$ & $1 / 139(0.7)$ & $22 / 4778(0.5)$ \\
B. burgdorferi & $0 / 4(0)$ & $16 / 139(11.5)$ & $676 / 4778(14.1)$ \\
A. phagocytophilum & $0 / 4(0)$ & $0 / 139(0)$ & $37 / 4778(0.8)$ \\
$\begin{array}{l}\text { Coinfections of B. miyamotoi and } \\
\text { B. burgdorferi }\end{array}$ & $0 / 4(0)$ & $0 / 139(0)$ & $8 / 4778(0.2)$ \\
$\begin{array}{l}\text { Coinfections of A. phagocytophilum } \\
\text { and B. burgdorferi }\end{array}$ & $0 / 4(0)$ & $0 / 139(0)$ & $11 / 4778(0.2)$ \\
\hline
\end{tabular}

*This table does not include data from 17 ticks for which instar was not recorded.

${ }^{+}$Collected by passive surveillance in 2012 . whose pathogenicity has not yet been determined. Here we have developed new assays and combined them with existing ones to create a PCR testing protocol, similar to that of Ullman et al. [13], which allowed us to detect and identify infections and co-infections of ticks with different Borrelia species and A. phagocytophilum. The new 16S-23S IGS real-time PCR assays were robust showing 100\% concordance between positive results and sequence analysis indicating high specificity. There was slight reactivity of $B$. hermsii DNA in the B. burgdorferi IGS real-time assay, but this is of little consequence on test outcomes as B. hermsii is transmitted by Argasid ticks and would rarely, if ever, be encountered in blacklegged ticks obtained in surveillance. Future refinements of this testing protocol will include implementation of a duplex real-time PCR assay for $B$. burgdorferi ospA and B. miyamotoi $16 \mathrm{~S}-23 \mathrm{~S}$ IGS to reduce PCR steps, development of a real-time PCR assay to detect $B$. bissettii and incorporation of PCR assays for nonbacterial I. scapularis-borne pathogens such as Powassan encephalitis virus.

By implementation of this new testing protocol for the detection of selected species of Borrelia, we have expanded on the findings of Ogden et al. [8] who first detected B. miyamotoi in blacklegged ticks collected in Canada. The prevalence of B. miyamotoi in blacklegged ticks in our study $(<1 \%)$ was lower than the $1-5 \%$ reported in the eastern USA $[2,3]$, and this difference may suggest that $B$. miyamotoi transmission cycles are at an early stage of becoming established amongst resident tick and rodent populations in Canada compared to localities in the USA [19]. Infection prevalence of tickborne pathogens in ticks and hosts may take some years to rise to an equilibrium level, particularly if the ticks are at low densities, being themselves at an early stage of becoming established [20]. However, our study also confirms that as in the US, B. miyamotoi can be detected across the geographic range of I. scapularis in Canada 
$[2,3,8]$. Geographic variations in the prevalence of $B$. burgdorferi and $A$. phagocytophilum infection in ticks were detected and these are consistent with previous studies. Low B. burgdorferi infection prevalence was detected in ticks from New Brunswick and Manitoba, which is consistent with previous analyses linking low B. burgdorferi infection prevalence in I. scapularis populations that are emerging in these locations [21,22], as well as in provinces where ticks from these new populations are likely carried by migratory birds (from $\mathrm{New}$ Brunswick into Prince Edward Island where no deer occur to permit ticks to establish, and from Manitoba into Alberta). There were no ticks submitted from Saskatchewan during this study period and ticks from Alberta would be expected to be 'adventitious' ticks dispersed by migratory birds from Manitoba or the upper Mid-West of the USA $[8,9,22]$. Higher infection prevalence of $A$. phagocytophilum in ticks from Manitoba and Alberta is consistent with spring synchrony of larval and nymphal $I$. scapularis tick activity in the west of the tick's range enhancing transmission of short-lived rodent host infections compared to the more asynchronous transmission in the east [20,23]. Higher infection $A$. phagocytophilum prevalence in ticks in some locations in Quebec has been detected possibly associated with founder events in naïve host populations [24,25]. In contrast to $B$. burgdorferi, there was no evidence of geographic variation (in the presented analysis as well as in cluster analysis not described here) in the prevalence of $B$. miyamotoi infection of ticks, which is consistent with more simultaneous introduction of $B$. miyamotoi with I. scapularis. As B. miyamotoi is transovarially and transtadially transmitted in ticks, this bacterium can be imported in host-dispersed infected engorged nymphal ticks as well as larval ticks, while only imported engorged larvae can efficiently introduce B. burgdorferi [22].

Variations in prevalence of $B$. burgdorferi infection with stage of engorgement are consistent with our findings in previous studies; $B$. burgdorferi multiplies in the tick as it feeds [21]. Variations in prevalence of B. burgdorferi infection with host of origin have also been observed in our passive surveillance data [21] although here ticks collected from humans were less likely to be detected as infected. The underlying reason for this variation is unknown; however an analysis of the quality of the submitted ticks did not indicate significant differences between ticks removed from humans or companion animals (data not shown). It is possible that ticks from dogs had higher infection prevalence than ticks from humans because some of the dogs were infected and consequently infective for ticks that fed on them [26]. Some I. scapularis ticks were co-infected with $B$. miyamotoi and B. burgdorferi or with $A$. phagocytophilum and $B$. burgdorferi however, co-infection with
B. miyamotoi and B. burgdorferi occurred more frequently than by chance, which is consistent with shared reservoirs for these species [20,27]. The implications of these observations for disease in humans are at present unknown and require further investigation, as does the occurrence of B. miyamotoi in I. pacificus ticks, the other main vector of tick-borne zoonoses that occurs in British Columbia.

\section{Conclusions}

The relatively limited (though expanding) distribution of blacklegged tick populations in Canada [22,28,29] and the lower prevalence of $B$. miyamotoi infection in these ticks means that at present the risk of infection of humans in Canada would be lower than in parts of the USA [6]. Nevertheless, our study indicated that B. miyamotoi is present across a wide geographic range in Canada, and clinicians should consider $B$. miyamotoi infection as a possible diagnosis, alongside Lyme disease, Anaplasmosis, Ehrlichiosis, Babesiosis and arboviral infections, in patients suffering from suspected infectious disease who have potentially been exposed to ticks in Canada. Our findings underline the need for improved diagnostics for B. miyamotoi and other tick-borne pathogens, and ongoing exploration for novel tick-borne pathogens.

\section{Competing interests}

The authors declare that they have no competing interests.

\section{Authors' contributions}

All authors have contributed significantly to either the bench work, the design of the study, data analysis or drafting of the manuscript. All authors read and approved the final version of the manuscript.

\section{Acknowledgements}

We are grateful to the veterinarians, medical health professionals and members of the general public who provided the I. scapularis ticks that were a central component of this study. This work would not have been possible without this collaboration.

\section{Author details}

${ }^{1}$ Public Health Agency of Canada, Zoonotic Diseases and Special Pathogens, National Microbiology Laboratory, 1015 Arlington Street, Winnipeg, Manitoba, Canada. ${ }^{2}$ Public Health Agency of Canada, Zoonoses Division, Centre for Food-borne Environmental and Zoonotic Infectious Diseases, Saint-Hyacinthe, Quebec, Canada.

Received: 3 January 2014 Accepted: 2 April 2014 Published: 15 April 2014

\section{References}

1. Fukunaga M, Takahashi Y, Tsuruta Y, Matsushita O, Ralph D, McClelland M, Nakao M: Genetic and phenotypic analysis of Borrelia miyamotoi sp. nov., isolated from the Ixodid tick Ixodes persulcatus, the vector for Lyme disease in Japan. Int J Syst Bacteriol 1995, 45(4):804-810.

2. Scoles $G A$, Papero $M$, Beati $L$, Fish D: A relapsing fever group spirochete transmitted by Ixodes scapularis ticks. Vector Borne Zoonotic Dis 2001, 1(1):21-34.

3. Rollend L, Fish D, Childs JE: Transovarial transmission of Borrelia spirochetes by Ixodes scapularis: a summary of the literature and recent observations. Ticks Tick-borne Dis 2013, 4(1-2):46-51.

4. Platonov AE, Karan LS, Kolyasnikova NM, Makhneva NA, Toporkova MG, Maleev W, Fish D, Krause PJ: Humans infected with relapsing fever 
spirochete Borrelia miyamotoi, Russia. Emerg Infect Dis 2011, 17(10):1816-1823.

5. Gugliotta JL, Goethert HK, Berardi VP, Telford SR III: Meningoencephalitis from Borrelia miyamotoi in an immunocompromised patient. New Engl Med 2013, 368(3):240-245.

6. Krause PJ, Narasimhan S, Wormser GP, Rollend L, Fikrig E, Lepore T, Barbour A, Fish D: Human Borrelia miyamotoi infection in the United States. New Engl J Med 2013, 368(3):291-293.

7. Chowdri HR, Gugliotta JL, Berardi VP, Goethert HK, Molloy PJ, Sterling SL, Telford SR III: Borrelia miyamotoi infection presenting as human granulocytic anaplasmosis: a case report. Ann Intern Med 2013, 159(1):21-27.

8. Ogden NH, Margos G, Aanensen DM, Drebot MA, Feil EJ, Hanincová K, Schwartz I, Tyler S, Lindsay LR: Investigation of genotypes of Borrelia burgdorferi in Ixodes scapularis ticks collected during surveillance in Canada. Appl Environ Microbiol 2011, 77(10):3244-3254.

9. Ogden NH, Trudel L, Artsob H, Barker IK, Beauchamp G, Charron DF, Drebot MA, Galloway TD, O'Handley R, Thompson RA, Lindsay LR: Ixodes scapularis ticks collected by passive surveillance in Canada: analysis of geographic distribution and infection with Lyme borreliosis agent Borrelia burgdorferi. J Med Entomol 2006, 43(3):600-609.

10. Koffi JK, Leighton PA, Pelcat Y, Trudel L, Lindsay LR, Milord F, Ogden NH: Passive surveillance for $I$. scapularis ticks: enhanced analysis for early detection of emerging Lyme disease risk. J Med Entomol 2012, 49(2):400-409.

11. Courtney JW, Kostelnik LM, Zeidner NS, Massung RF: Multiplex real-time PCR for detection of Anaplasma phagocytophilum and Borrelia burgdorferi. J Clin Microbiol 2004, 42(7):3164-3168.

12. Scott JC: Typing African relapsing fever spirochetes. Emerg Infect Dis 2005, 11(11):1722-1729.

13. Ullmann AJ, Gabitzsch ES, Schulze TL, Zeidner NS, Piesman J: Three multiplex assays for detection of Borrelia burgdorferi sensu lato and Borrelia miyamotoi sensu lato in field-collected Ixodes nymphs in North America. J Med Entomol 2005, 42(6):1057-1062.

14. Ogden NH, Lindsay RL, Hanincová K, Barker IK, Bigras-Poulin M, Charron DF, Heagy A, Francis CM, O'Callaghan CJ, Schwartz I, Thompson RA: Role of migratory birds in introduction and range expansion of Ixodes scapularis ticks and of Borrelia burgdorferi and Anaplasma phagocytophilum in Canada (Applied and Environmental Microbiology (2008) 74, 6, (1780-1790)). Appl Environ Microbiol 2008, 74(12):3919.

15. Pritt BS, Sloan LM, Johnson DK, Munderloh UG, Paskewitz SM, McElroy KM, McFadden JD, Binnicker MJ, Neitzel DF, Liu G, Nicholson WL, Nelson CM, Franson JJ, Martin SA, Cunningham SA, Steward CR, Bogumill K, Bjorgaard ME, Davis JP, McQuiston JH, Warshauer DM, Wilhelm MP, Patel R, Trivedi VA, Eremeeva ME: Emergence of a new pathogenic Ehrlichia species, Wisconsin and Minnesota, 2009. N Engl J Med 2011, 365(5):422-429.

16. Krause PJ, McKay K, Thompson CA, Sikand VK, Lentz R, Lepore T, Closter L, Christianson D, Telford SR, Persing D, Radolf JD, Spielman A, DeerAssociated Infection Study Group: Disease-specific diagnosis of coinfecting tickborne zoonoses: babesiosis, human granulocytic ehrlichiosis, and Lyme disease. Clin Infect Dis 2002, 34(9):1184-1191.

17. Rudenko N, Golovchenko M, Grubhoffer L, Oliver JH Jr: Borrelia carolinensis sp. nov., a new (14th) member of the Borrelia burgdorferi Sensu Lato complex from the southeastern region of the United States. J Clin Microbiol 2009, 47(1):134-141.

18. Schneider BS, Schriefer ME, Dietrich G, Dolan MC, Morshed MG, Zeidner NS: Borrelia bissettii isolates induce pathology in a murine model of disease. Vector Borne Zoonotic Dis 2008, 8(5):623-633.

19. Bouchard C, Beauchamp G, Leighton PA, Lindsay R, Belanger D, Ogden NH: Does high biodiversity reduce the risk of Lyme disease invasion? Parasit Vectors 2013, 6:195-3305. -6-195.

20. Ogden NH, Bigras-Poulin M, O'Callaghan CJ, Barker IK, Kurtenbach K, Lindsay LR, Charron DF: Vector seasonality, host infection dynamics and fitness of pathogens transmitted by the tick lxodes scapularis. Parasitology 2007, 134(2):209-227.

21. Ogden NH, Bouchard C, Kurtenbach K, Margos G, Lindsay LR, Trudel L, Nguon S, Milord F: Active and passive surveillance and phylogenetic analysis of Borrelia burgdorferi elucidate the process of Lyme disease risk emergence in Canada. Environ Health Perspect 2010, 118(7):909-914.

22. Ogden NH, Lindsay $L R$, Leighton PA: Predicting the rate of invasion of the agent of Lyme disease Borrelia burgdorferi. J Appl Ecol 2013, 50(2):510-518.
23. Gatewood AG, Liebman KA, Vourc'h G, Bunikis J, Hamer SA, Cortinas R, Melton F, Cislo P, Kitron U, Tsao J, Barbour AG, Fish D, Diuk-Wasser MA: Climate and tick seasonality are predictors of Borrelia burgdorferi genotype distribution. Appl Environ Microbiol 2009, 75(8):2476-2483.

24. Bouchard C, Leighton PA, Beauchamp G, Nguon S, Trudel L, Milord F, Lindsay LR, Bélanger D, Ogden NH: Harvested white-tailed deer as sentinel hosts for early establishing Ixodes scapularis populations and risk from vector-borne zoonoses in Southeastern Canada. J Med Entomol 2013, 50(2):384-393.

25. Ogden NH, Mechai S, Margos G: Changing geographic ranges of ticks and tick-borne pathogens: drivers, mechanisms and consequences for pathogen diversity. Front Cell Infect Microbiol 2013, 3:46.

26. Mather TN, Fish D, Coughlin RT: Competence of dogs as reservoirs for Lyme disease spirochetes (Borrelia burgdorferi). J Am Vet Med Assoc 1994, 205(2):186-188.

27. Barbour AG, Bunikis J, Travinsky B, Hoen AG, Diuk-Wasser MA, Fish D, Tsao J: Niche partitioning of Borrelia burgdorferi and Borrelia miyamotoi in the same tick vector and mammalian reservoir species. Am J Trop Med Hyg 2009, 81(6):1120-1131.

28. Ogden NH, St.-Onge L, Barker IK, Brazeau S, Bigras-Poulin M, Charron DF, Francis CM, Heagy A, Lindsay LR, Maarouf A, Michel P, Milord F, O'Callaghan CJ, Trudel L, Thompson RA: Risk maps for range expansion of the Lyme disease vector, Ixodes scapularis, in Canada now and with climate change. Int J Health Geogr 2008, 7:24

29. Leighton PA, Koffi JK, Pelcat Y, Lindsay LR, Ogden NH: Predicting the speed of tick invasion: An empirical model of range expansion for the Lyme disease vector Ixodes scapularis in Canada. J Appl Ecol 2012, 49(2):457-464.

doi:10.1186/1756-3305-7-183

Cite this article as: Dibernardo et al:: The prevalence of Borrelia miyamotoi infection, and co-infections with other Borrelia spp. in Ixodes scapularis ticks collected in Canada. Parasites \& Vectors 2014 7:183.

\section{Submit your next manuscript to BioMed Central and take full advantage of:}

- Convenient online submission

- Thorough peer review

- No space constraints or color figure charges

- Immediate publication on acceptance

- Inclusion in PubMed, CAS, Scopus and Google Scholar

- Research which is freely available for redistribution 